\title{
TURKISH SHIPOWNERS' PERCEPTIONS OF THIRD PARTY SHIP MANAGEMENT COMPANIES: A MARKET RESEARCH STUDY*
}

\author{
İsmail Bilge ÇETIN ${ }^{1}$ \\ A. Güldem CERIT ${ }^{2}$
}

\begin{abstract}
The aim of this study is to analyze the Turkish ship owners' perceptions of third party ship management companies and the demands for the services of these companies from Turkish shipowners. As a methodology, literature review and telephone structured interviews have been utilized. The frequency analysis as a statistical method was used to analyze the results of the interviews. The population of the study consists of the Turkish shipowners who have any kinds of vessels with the capacity of 1000 gross tons and over. The results of the study revealed that big portion of Turkish shipowners, $80 \%$ of the sample, are not willing to give their vessels to the management of third party ship management companies. Although a small portion of owners takes on the management services, they do not frequently assign full management to third parties. This is because of the fact that Turkish shipowners traditionally operate their vessels themselves and they prefer to have complete control over them. In fact, Turkish shipowners joining the study do not trust in the third party ship management companies. Even the owners using the third party management companies prefer to keep complete control over the management companies.
\end{abstract} research.

Key words: Third party ship management, ship owning, market

\footnotetext{
* This paper is revised version of an earlier study that was presented and published in the conference proceedings at the 7th International Conference on Business, Management and Economics organized by Yasar University, Cesme-Izmır, Turkey on 6th-8th October 2011.

${ }^{1}$ Dokuz Eylul University, Maritime Faculty, ismail.cetin@deu.edu.tr

${ }^{2}$ Dokuz Eylul University, Maritime Faculty, gcerit@deu.edu.tr
} 


\section{ÖZET}

Bu çalışmanın amacl, Türk armatörlerinin üçüncü taraf gemi yönetim işletmelerini ne şekilde alglladıklarını ortaya koymak ve Türk armatörlerinin bu işletmelerin sunmuş oldukları hizmetlere olan taleplerini analiz etmektir. Çalışmada yöntem olarak, literatür taraması ve biçimsel telefonla mülakat yöntemi kullanılmıştır. Mülakat sonuçlarının değerlendirilmesinde istatistiksel bir yöntem olan frekans analizi kullanılmıştır. Çalışmanın ana kütlesi 1000 gros ton ve üzeri her tipte gemiye sahip armatörlerlerden oluşmaktadır. Çalışma sonrasında örneklemdeki armatörlerden \% 80'inin gemilerini üçüncü taraf gemi yönetimi işletmelerinin yönetimine vermeye istekli olmadıkları ortaya çıkmıştır. Her ne kadar küçük bir grup armatör, gemi yönetim işletmelerinden hizmet alsalar da bu hizmetler sürekli ve tam gemi yönetim hizmetlerini içermemektedir. Bu sonuçtaki en büyük etken Türk armatörlerinin geleneksel olarak gemilerini kendilerinin yönetmesi ve gemileri üzerinde tam bir kontrol kurma isteğ $i$ olarak ortaya çıkmaktadır. Gerçekte, çalışmaya katılan Türk armatörlerinin üçüncü taraf gemi yönetim işletmelerine güvenmedikleri görülmektedir. Gemilerini gemi yönetim işletmelerinin kontrolüne veren armatörler dahi gemileri üzerinde tam bir kontrol kurma isteğindedirler.

Anahtar Kelimeler: Üçüncü taraf gemi yönetimi, armatörlük, pazar araştırmast.

\section{INTRODUCTION}

In the last days of sail and early days of steam, ships were self-managed. Communications were so poor that the shipowners had no option but to trust his shipmasters once the ships were out of sight of the home port. Of necessity the master had to make all the short term decisions including those associated with the employment of the ship. As communications improved it became easier to instruct and thus control the ship; and much of the decision making on major technical, supplies, and crew matters, moved from the ships to the head Office (Downard, 1996). The management of the ships by the shipowners continued until 1957 in which the first third-party ship management contract was signed between a shipowner and a professional ship management company. From the time of the signing of the first such third-party ship management contract, professional ship management evolved into an industry in its own right (Mitroussi, 2004a). As it is seen, the provision of ship management services by third parties is a relatively new type of service in international shipping when compared to the time period during which ships have 
been managed by their owners. Panayides (2001) in his study states that professional ship management represents a major structural change in the maritime industry. The first way was the early use of water transport by man, followed by the quest for maritime power occurring in the 17th and 19th centuries. The third wave began after the Second World War and culminated in the transnationalization of shipping with the greatly increased dependence on manpower from developing countries and flagging out. The forth wave in the international shipping is the professional ship management.

What is third party ship management or professional ship management? "Third party ship management can be defined as the professional supply of a single or a range of services by a management company separate from the vessel's ownership where "professional supply" means that the supplier (ship manager) provides service(s) to the user (shipowner) according to contracted terms and in return for a management fee”. In doing so, the ship manager is required to ensure that the vessel always complies with international rules and regulations is run in safe and cost efficient manner without threat to the environment and is maintained so as to preserve as far as possible its asset value (Willingale et al., 1998).

The growth and the importance of ship management have been recognized since early 1970s. This is documented in the report prepared by Committee of Inquiry into Shipping chaired by Viscount Rochdale (The Rochdale Report) and presented to the British Parliament in 1970 (Panayides, 2001). The report recognized that:

"There is an important part to be played by good independent ship management companies to help the small owner in developing his business. There may also be special circumstances where some larger companies may benefit from their employment. We regard the existence of good independent professional management companies as conductive to efficiency in the industry" (Panayides, 2001).

Besides the Rochdale Report, BIMCO (2011) also indicates the importance of ship management companies as follows: "There are numerous advantages in employing ship managers, not least the ability to outsource many difficult and labor intensive elements of ship operation and management. It is an arrangement that suits an industry where demand for ships and shipping is notoriously cyclical. It also 
enables an owner of perhaps just a few ships to operate them without the need for a large in-house organization. Moreover, placing this small fleet with a sizeable ship management company will generate the advantages of being with a large fleet, such as excellent purchasing power for stores, repairs and other matters which the large manager will be able to obtain. And as the operation of ships becomes more heavily regulated, the demand for these "ships' husbands" (which they were called in the past, continues to grow."

Although one third of the world's fleet is in the hands of ship management companies (BIMCO, 2011), this sector is not well developed in Turkey as it has done in some other maritime countries. Due to this fact, this study aimed to analyze the Turkish shipowners' perceptions of third party ship management companies and the demands for the services of these companies from Turkish shipowners. Although this study is the first study in this field in Turkey, similar studies were made by Mitroussi (2003; 2004a; 2004b).

In the study, Section 1 involves "introduction" wherein the emergence, development throughout the history up to the present situation and definition of ship management companies as well as in what respects they differ from ship owning companies. Section 2 is addressed to overall literature review through which the studies published in this particular topic were reviewed. Section 3 covers evolution of ship management and place of third party ship management companies. Section 4 is the overall evaluation of services offered by ship management companies in accordance with "BIMCO Shipman 98 and Shipman 2009 standard ship management agreement contract". Section 5 introduces the analysis of the number of the ship management companies both in the world in general and in Turkey in particular as well as the services they have offered. Section 6 investigates the Turkish shipowners' perceptions of third party ship management companies and the demands for the services of these companies from Turkish shipowners. As a methodology, literature review and telephone structured interviews have been utilized. The sample is Turkish shipowners fleet which consists of vessels of 1000 Gross Tons and above. Section 7 provides conclusions and discussions. The results of the study will give an understanding of market potential of third party ship management companies in Turkey and Turkish shipowners' perceptions of third party ship management companies. 


\section{LITERATURE REVIEW}

The studies in the relevant literature on third party ship management companies are very limited. The articles which were reviewed can be classified as follows: The third party ship management companies and their role in shipping (Sletmo, 1986; Sletmo, 1989; Uderwood, 1989), organizational charecteristics of shipowning companies and the use of third party ship management by shipowning companies (Mitroussi 2003; Mitroussi 2004a; Mitroussi 2004b), marketing the ship management services (Panayides and Gray, 1997), competitive advantage in ship management (Panayides and Gray, 1999; Panayides, 2003), third party ship management selection and evaluation (Panayides and Cullinan, 2002), integrated process management system (IPMS) in ship management companies (Celik, 2009), corporate governance and board practices by Greek shipping management companies (Koufopoulos et al., 2010), crew management (Klikauer and Morris, 2003; Chin, 2008). Besides these articles, there are some books on ship management written by Willingale et al., 1998; Downard, 1996; Tallack, 2000; Raghuram et al., 1998; Gilberth, 1993; Panayides, 2001.

\section{EVOLUTION OF SHIP MANEGEMENT AND PLACE OF THIRD PARTY SHIP MANAGEMENT COMPANIES}

All ships were before the existence of the third party ship management companies and many ships today are managed by traditional ship owning companies. This management method is called "In-House management". In this type of management, management functions are performed under the auspices of the owning company, which controls the day-to-day operations of the companies' vessels. In this type of management organizations, third party vessels are not managed (Panayides, 2001; 14).

In the second stage of the evolution process of the ship management companies, "third party ship management" or "independent" ship management companies came into play. These companies, as explained before, manage vessels for third parties and have no equity stake in the vessels or have no vessels of their own (Panayides, 2001; 14). The development of third party ship management represented an instance of true change in the shipping 
business. It signified a shift from traditional ways of running business in shipping on to a new model that assigned the role of the owner and the role of the manager to two different entities (Mitroussi, 2004a). With the employment of third party managers, despite the fact that the offices of a shipping company remain ashore and perhaps under the control of the owner, the real asset, in which huge capital investments have been made and from which the profits of the company are expected to derive - the vessel—is in the hands of others (Mitroussi, 2004a).

The third stage in ship management is "Owner-Managing" companies. In these companies some owners have diversified into performing ship management functions for other ship owners. These owners operate under hybrid arrangement, managing vessels for other owners in addition to their own ships (Panayides, 2001; 15).

The latest development in ship management is "Manager-Owning" companies. It was brought about by the increase in size and financial capacity of third party ship management companies who decided to invest in ship purchase and manage the acquired vessels and trade them for profit. Their main function, however, is still the provision of third party services (Panayides, 2001; 15).

\section{SERVICES OF THIRD PARTY SHIP MANAGEMENT COMPANIES}

The services that may be offered by ship managers have grown to include virtually anything required to run a ship profitably but excluding, however, the provision of equity finance (Panayides, 2001). In BIMCO'S standard ship management document called BIMCO Shipman (1998) and BIMCO Shipman (2009), one can find explicitly outlined the variety of levels of management services that ship owners have at their disposal. In broad terms, these include crewing, technical management, insurance, freight management, accounting, chartering, sale and purchase, provisions, bunkering and operations.

In case a ship management company is accepted to give a full management service, that company is expected to serve at least two basic services which are technical management and crew management services (Willingale et al., 1998). 


\section{THIRD PARTY SHIP MANAGEMENT COMPANIES IN THE WORLD AND IN TURKEY}

According to the data of InterManager (2011), which is the international trade association for the ship management industry, the association currently has 33 full member managers and these managers are collectively involved in the management of more than 4,370 ships and responsible for some 250,000 seafarers. Some major ship management companies around the world is given in Table 1.

Ship management companies are mainly located in world's shipping centers. Some of such locations are The United Kingdom, Germany, Cyprus, Greece, Hong Kong, Norway, Singapore and the Unites States of America (Panayides, 2001).

Table 1.Major Third Party Ship Management Companies in the World.

\begin{tabular}{|l|l|l|l|}
\hline \multicolumn{1}{|c|}{ Name of company } & \multicolumn{1}{|c|}{$\begin{array}{c}\text { Minumum } \\
\text { Services } \\
\text { rendered }\end{array}$} & \multicolumn{1}{|c|}{$\begin{array}{c}\text { Management } \\
\text { Type }\end{array}$} & Ship Types \\
\hline $\begin{array}{l}\text { Aboitiz Jebsen Bulk } \\
\text { Transport Corp. }\end{array}$ & Full management & Independent & All ship \\
\hline $\begin{array}{l}\text { Anglo-Eastern (Ship) } \\
\text { Management }\end{array}$ & Full management & Independent & All ship \\
\hline $\begin{array}{l}\text { ASP Ship } \\
\text { Management Group }\end{array}$ & Full management & Independent & All ship \\
\hline $\begin{array}{l}\text { Bernhard Schulte Ship } \\
\text { Management }\end{array}$ & Full management & Independent & All ship \\
\hline $\begin{array}{l}\text { Bibby Ship } \\
\text { Management }\end{array}$ & Full management & Independent & All ship \\
\hline $\begin{array}{l}\text { Columbia Ship } \\
\text { Management Ltd }\end{array}$ & Full management & Independent & All ship \\
\hline $\begin{array}{l}\text { Diamond Ship } \\
\text { Management }\end{array}$ & Full management & Independent & All ship \\
\hline $\begin{array}{l}\text { Fleet Management } \\
\text { Limited }\end{array}$ & Full management & Independent & All ship \\
\hline Haque and Sons Ltd & $\begin{array}{l}\text { Crew } \\
\text { management }\end{array}$ & Independent & All ship \\
\hline $\begin{array}{l}\text { International Shipping } \\
\text { Partners Inc }\end{array}$ & Full management & Independent & Passanger \\
\hline
\end{tabular}


Table 1.Major Third Party Ship Management Companies in the World. (Continued)

\begin{tabular}{|l|l|l|l|}
\hline \multicolumn{1}{|c|}{ Name of company } & \multicolumn{1}{|c|}{$\begin{array}{c}\text { Minumum } \\
\text { Services } \\
\text { rendered }\end{array}$} & $\begin{array}{c}\text { Management } \\
\text { Type }\end{array}$ & Ship Types \\
\hline $\begin{array}{l}\text { OSM Ship Management } \\
\text { AS }\end{array}$ & Full management & Independent & All ship \\
\hline $\begin{array}{l}\text { Terra Marine Ship } \\
\text { Management (Pvt) Ltd }\end{array}$ & Full management & Independent & All ship \\
\hline $\begin{array}{l}\text { Thome Ship } \\
\text { Management Pte Ltd }\end{array}$ & Full management & Independent & All ship \\
\hline V. Ships & Full management & Independent & All ship \\
\hline Wilhelmsen Services & Full management & Independent & All ship \\
\hline
\end{tabular}

Source: Compiled from web pages of the above listed companies.

There are several ship management companies in Turkey. However, the number of third party ship management (independent management) companies is very limited. Some of the selected ship management companies are given in Table. 2. Ship management companies in Turkey are either "owner- managing" type companies which manage other Turkish or foreign ship owners' vessels beside their own fleet or purpose-built management companies which are established to manage the shipowners own flagged-out ships. The owners preferring to operate their vessels under foreign flag, have to establish a ship owning company in the flagged out country. However, these owners usually prefer to manage their own vessels from Turkey by conducting a ship management contract between their company in flagged out country and the purpose-built management company established in Turkey by themselves. Because of the managerial preferences of the Turkish shipowners, third party ship management companies have very limited market potentials. 
Table 2. Third Party Ship Management Companies in Turkey.

\begin{tabular}{|l|l|l|l|}
\hline \multicolumn{1}{|c|}{$\begin{array}{c}\text { Name of } \\
\text { company }\end{array}$} & \multicolumn{1}{|c|}{ Services } & Management Type & Ship Types \\
\hline V. Ships (Turkey) & Full management & Independent & All types \\
\hline Chemfleet & Full management & Independent & $\begin{array}{l}\text { All types - } \\
\text { Focusing on } \\
\text { Chemical } \\
\text { tanker }\end{array}$ \\
\hline $\begin{array}{l}\text { Densa Ship } \\
\text { Management }\end{array}$ & Full management & Independent & $\begin{array}{l}\text { Oil - Chemical } \\
\text { tanker }\end{array}$ \\
\hline $\begin{array}{l}\text { Istanbul Ship } \\
\text { Management S.A. }\end{array}$ & Full management & Managing-Owner & All types \\
\hline $\begin{array}{l}\text { Konvoy } \\
\text { Denizcilik }\end{array}$ & Full management & Managing-Owner & Dry Bulk \\
\hline $\begin{array}{l}\text { Cornships } \\
\text { Management and } \\
\text { Agency Inc. }\end{array}$ & Full management & Owner-Managing & Dry bulk carries \\
\hline $\begin{array}{l}\text { Palmali Shipping } \\
\text { Co. }\end{array}$ & Full management & Owner-Managing & $\begin{array}{l}\text { Tankers, LPG } \\
\text { and oil product } \\
\text { carriers }\end{array}$ \\
\hline
\end{tabular}

Source: Compiled from web pages of the above listed companies

\section{AIM OF THE STUDY}

The aim of this study is to analyze the Turkish shipowners' perceptions of third party ship management companies and the demands for the services of these companies from Turkish dry bulk shipowners.

\subsection{Restrictions of the Study}

The study is applied for Turkish ship owning companies which have any kinds of vessels with the capacity of 1000 gross tons and over.

\subsection{Methodology of the Study}

A two-staged method was used for the study. In the 1st stage, second hand data sources were searched in detail to determine the factors which have effects on analyzing to analyze the shipowners' perceptions of third party ship management companies. 
In the second stage, Turkish dry bulk shipowners' perceptions of third party ship management companies and the demands for the services of these companies were evaluated by conducting interviews with managers who are actively involved in ship owning and ship management companies.

\subsubsection{Interview}

In the study, telephone structured interviews were used, which are closely comparable to personal ones in terms of response rate, quality of data and respondents' motivation.

25 Turkish ship owning and 2 third party ship management companies which have offices in Izmir and Istanbul were interviewed in order to determine the variables in the interview question. Each interview took 5-15 minutes on average. Some of the respondents were called several times in order to clarify the questions. In general, satisfactory and purpose-oriented answers were received to the questions, which were prepared before interviews.

\subsubsection{Generation of the Questionnaire}

An interview question form with 2 parts were prepared to identify the Turkish owners' perceptions of third party ship management companies and the demands for the services of these companies. First part consists of 6 questions which will reveal the profiles of ship owning company. Second part consists of 4 main questions each of which has several sub questions which evaluates Turkish shipowners tendency towards ship management companies.

The questions used in the interviews with ship owners and third party ship management companies were formed making use of the data collected from the relevant literature Mitroussi (2004a and 2004b) and the pre interviews conducted with the ship owners in Izmir.

\subsubsection{Population and Sample}

The population of the study is the ship owners which operate their vessels under Turkish and foreign flags and which have all types of ships with a capacity 1000 Gross Tons and over, which conduct 
operations actively. Turkish shipowners in the population have 1222 ships whose dead weight capacity is 16,768,968 tons (See Table. 3).

Table 3. Turkish Shipowners' Fleets (dwt), as at 1 January 2010

\begin{tabular}{|c|c|c|c|c|c|c|c|c|c|}
\hline & & & er of vess & & & & Deadweight to & & \\
\hline & $\begin{array}{c}\text { Country or territory } \\
\text { of ownership }\end{array}$ & $\begin{array}{c}\text { National } \\
\text { flag }\end{array}$ & $\begin{array}{c}\text { Foreign } \\
\text { flag }\end{array}$ & Total & $\begin{array}{c}\text { National } \\
\text { flag }\end{array}$ & $\begin{array}{l}\text { Foreign } \\
\text { flag }\end{array}$ & Total & $\begin{array}{l}\text { Foreign flag as } \\
\text { apercentage of } \\
\text { total }\end{array}$ & $\begin{array}{c}\text { Total as a } \\
\text { percentage } \\
\text { of world total, } \\
1 \text { Jan. } 2010\end{array}$ \\
\hline 1 & Greece & 741 & 2409 & 3150 & 58478197 & 127616965 & 186095162 & 69 & 15.96 \\
\hline 2 & Japan & 720 & 3031 & 3751 & 14443324 & 168876356 & 183319680 & 92 & 15.73 \\
\hline 3 & China & 2024 & 1609 & 3633 & 41026075 & 63426314 & 104452389 & 61 & 8.96 \\
\hline 4 & Germany & 458 & 3169 & 3627 & 16926387 & 86969282 & 103895669 & 84 & 8.91 \\
\hline 5 & Republic of Korea & 775 & 425 & 1200 & 18865348 & 26017970 & 44883318 & 58 & 3.85 \\
\hline & & & & & & & & & \\
\hline 17 & India & 443 & 66 & 509 & 14280882 & 2885687 & 17166569 & 17 & 1.47 \\
\hline 18 & Turkey & 558 & 664 & 1222 & 7139310 & 9629658 & 16768968 & 57 & 1.44 \\
\hline & World total & 17279 & 21133 & 38412 & $\begin{array}{r}368251 \\
867\end{array}$ & 797468296 & 1165720163 & 68 & 100.00 \\
\hline
\end{tabular}

A Vessels of 1,000 GT and above, ranked by deadweight tonnage.

Source: UNCTAD (2010) Review of Maritime Transport

The sample was determined by the convenience sampling methods. By considering the population and goals of the study and considerations of cost and limitations, our sample was determined as $64 \%$ of the population. However, responses from only 27 companies which have the ship capacity of 10,784,308 dwt were received. This sample represents the $64 \%$ of the whole population.

\subsection{Research Results}

Findings obtained through the interview method were explained in three parts. In the first part, profile information of the participants companies was given, while in the second part; profile information of the ship owning companies was explained. In the last and third part Turkish shipowner's perceptions of third party ship management companies were evaluated.

\subsubsection{Profile of the Respondents}

Findings related to the profile variables of participants are given in Table 4 . According to the findings, $33 \%$ of the participants are at general manager positions in their company. Technical 
managers and commercial manager are the second biggest respondent groups with an equal rate of $19 \%$. The shipowners, DPAs and operation managers follow the first three groups accordingly.

Table 4. Profile of the Respondents

\begin{tabular}{|l|c|}
\hline $\begin{array}{l}\text { Position of the Participants in the their } \\
\text { Company }\end{array}$ & \\
\hline Ship owner & $3(11 \%)$ \\
\hline General Manager & $9(33 \%)$ \\
\hline Designated Person Ashore (DPA) & $3(11 \%)$ \\
\hline Technical Manager & $5(19 \%)$ \\
\hline Commercial Manager / Chartering Manger & $5(19 \%)$ \\
\hline Operation Manager & $2(7 \%)$ \\
\hline Total & $\mathbf{2 7 ( 1 0 0 \% )}$ \\
\hline
\end{tabular}

Source: Authors

\subsubsection{Profile of the Companies}

In the first part of the study, type of companies, number of ships operated by ship owning and third party ship management companies, capacity of the ships operated by both ship owning and third party management companies and flags of the ships operated by ship owning and third party management companies were subjected to frequency analysis. Findings are given in Tables 5, 6 and 7.

Table 5.Profile of the Companies

\begin{tabular}{|c|c|c|c|c|}
\hline \multicolumn{5}{|c|}{ Type of Company } \\
\hline $\begin{array}{c}\text { Ship } \\
\text { Owning }\end{array}$ & $\begin{array}{c}\text { Owner- } \\
\text { Managing }\end{array}$ & $\begin{array}{c}\text { Manager- } \\
\text { Owning }\end{array}$ & $\begin{array}{c}\text { Third Party } \\
\text { Ship } \\
\text { Management }\end{array}$ & Total \\
\hline $16(59 \%)$ & $8(30 \%)$ & $1(3,5 \%)$ & $2(7,5 \%)$ & $27(100 \%)$ \\
\hline
\end{tabular}

Source: Authors

In the study, first question was regarding the type of the companies. As it is seen in Table 5, 16 participants stated that they are ship owning companies. This group constitutes the biggest part in the sample. 8 participants stated that they are owner-managers. Besides their own vessels, they have the ability to manage other owners' 
vessels. 2 participants presented themselves as third party ship management companies and 1 participant defined himself as a manager owning company. However, except 2 third party ship management companies, none of the other companies currently operate other shipowners' ships. While analyzing other companies rather than third party ship management companies, 9 out of 25 companies are the biggest companies of Turkey, remaining 16 companies are small and medium size ship owning companies. The study revealed that there are very limited third party ship management companies in Turkey. This is due to the lack of demand for these companies in Turkey.

Table 6. Number, Capacity and Flag of Ships Operated by Shipowners.

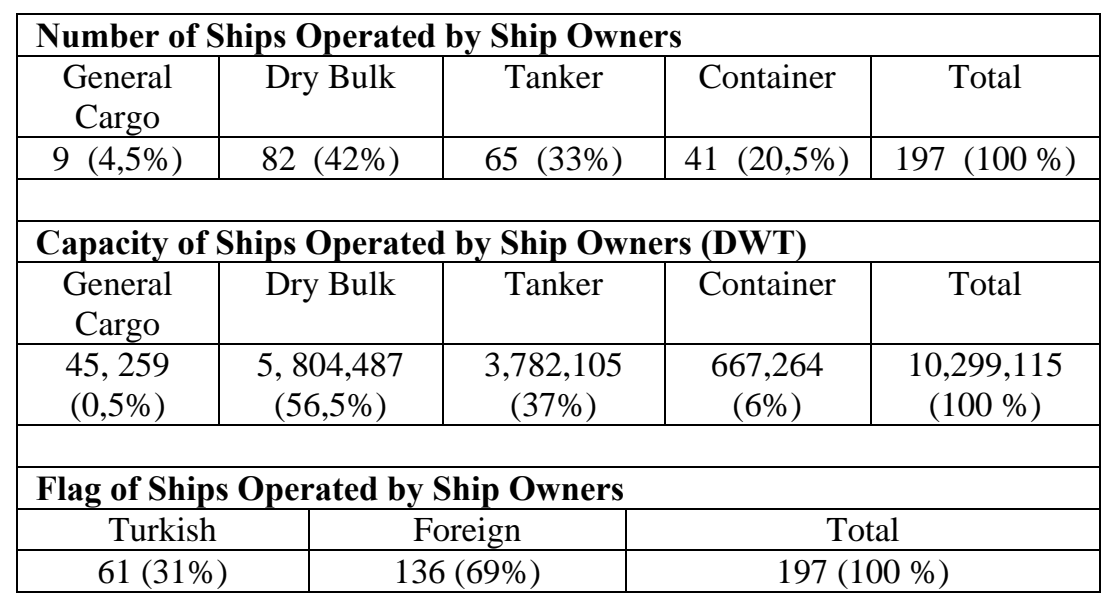

Source: Authors

In Table 6, since shipowning, owner-managing and managerowning companies operate their own vessels, they were put into the same category. The participants stated that they had 82 dry bulk carriers. This number constitutes $42 \%$ of total ships operated by the ship owners and generate the group with the biggest percentage. Tanker owners takes second place with 65 ships, which has a percentage of $65 \%$. 2 liner operator companies with 41 container ships have a percentage of $20.5 \%$.

Total percentage of dry bulk and tanker owners is determined as $75 \%$, which is a significant amount for the whole sample group. 
Analyzing these dispersions, it was observed that the participants were mainly owners of dry bulk carriers and tankers. This situation overlaps with the current fleet composition of Turkey.

Although the number of vessels in the study is totally 197 which, is only $16 \%$ of the population, the capacity of these vessels are $10,299,115$ DWT which is $61 \%$ of the population. The reason of this huge difference aroused from the carrying capacity of the ships in the sample group. These vessels are owned mainly by nine big ship owning companies and they consist of panamax and over types of bulkers and aframax and over types of tankers.

While $61 \%$ of the owners' vessels are operated under Turkish flag, $69 \%$ are operated under foreign flags. A ship owner who wants to operate his foreign flag ships under his command has to establish a ship management company in Turkey. This is the solution to operate the vessels from Turkey for many Turkish shipowners. By using this method, there is no requirement for the third party ship management companies.

Table 7. Number, Capacity and Flag of Ships Operated by Third Party Ship Management Companies

\begin{tabular}{|c|c|c|c|c|}
\hline \multicolumn{5}{|c|}{$\begin{array}{l}\text { Number of Ships Managed by Third Party Ship Management } \\
\text { Companies }\end{array}$} \\
\hline $\begin{array}{l}\text { General } \\
\text { Cargo }\end{array}$ & Dry Bulk & Tanker & Container & Total \\
\hline- & $8(23 \%)$ & $27(77 \%)$ & - & $35(100 \%)$ \\
\hline \multicolumn{5}{|c|}{$\begin{array}{l}\text { Capacity of Ships Managed by Third Party Ship Management } \\
\text { Companies (DWT) }\end{array}$} \\
\hline $\begin{array}{l}\text { General } \\
\text { Cargo }\end{array}$ & Dry Bulk & Tanker & Container & Total \\
\hline- & $\begin{array}{l}240,000 \\
(51 \%)\end{array}$ & $\begin{array}{c}236,693 \\
(49 \%)\end{array}$ & - & $\begin{array}{l}485,193 \\
(100 \%)\end{array}$ \\
\hline \multicolumn{5}{|c|}{ Flag of Ships Operated by Third Party Ship Management Companies } \\
\hline \multicolumn{3}{|l|}{ Turkish } & \multicolumn{2}{|c|}{ Total } \\
\hline $8(23 \%)$ & \multicolumn{2}{|c|}{$27(77 \%)$} & \multicolumn{2}{|c|}{$35(100 \%)$} \\
\hline
\end{tabular}

Source: Authors 
The vessels managed by the third party ship management companies consist of tankers and dry bulkers (See Table 7). In terms of numbers, the tankers with $77 \%$ takes the first place. This means that major customers of the management companies in Turkey is tanker owners. In fact, these owners are mainly the owners of coaster size chemical and oil product tankers. Although number of tankers is higher than dry bulkers, the capacity of dry bulkers and tankers is equally distributed. This is due to the fact that while dry bulkers are mainly handy and handymax size vessels, tankers are all coasters. While the flag of the ships managed by management companies is analyzed, it is seen that 27 ships out of 35 is foreign flag ships while 8 vessels are Turkish flagged.

\subsubsection{Usage of Third Party Ship Management Companies by Turkish Ship Owners}

In this section, since only the ship owners' perception are evaluated, 25 shipowners were taken into the consideration from the sample and 2 third party ship management companies were exempted.

Table 8 gives us the picture of the ship-owning sample in respect of their choice to use or not third-party ship management for their vessels. Clearly the majority of the total sample, $80 \%$, does not indicate any use of third-party managers for their fleets and only $8 \%$ are currently employing some form of third-party ship management for their ships, with a percentage in the order of $12 \%$ stating that they used to use third-party ship management in the past but they no longer do so. 
Table 8. Usage of Ship Management by Ship Owners

\begin{tabular}{|c|c|c|c|c|c|}
\hline $\begin{array}{l}\text { Use of ship } \\
\text { management }\end{array}$ & Dry Bulk & $\begin{array}{c}\text { Tanker / } \\
\text { Chemical } \\
\end{array}$ & $\begin{array}{c}\text { General } \\
\text { Cargo }\end{array}$ & Other & Total \\
\hline Yes & $\begin{array}{c}1 \\
(8 \%)\end{array}$ & $\begin{array}{c}1 \\
(20 \%)\end{array}$ & - & - & $\begin{array}{c}2 \\
(8 \%)\end{array}$ \\
\hline Yes but not now & - & - & $\begin{array}{c}3 \\
(50 \%) \\
\end{array}$ & - & $\begin{array}{c}3 \\
(12 \%)\end{array}$ \\
\hline No & $\begin{array}{c}11 \\
(92 \%) \\
\end{array}$ & $\begin{array}{c}4 \\
(80 \%) \\
\end{array}$ & $\begin{array}{c}3 \\
(50 \%) \\
\end{array}$ & $\begin{array}{c}2 \\
(100 \%) \\
\end{array}$ & $\begin{array}{c}20 \\
(80 \%) \\
\end{array}$ \\
\hline $\begin{array}{l}\text { No but thinking } \\
\text { about it }\end{array}$ & - & - & - & - & - \\
\hline Total & $\begin{array}{c}12 \\
(100 \%)\end{array}$ & $\begin{array}{c}5 \\
(100 \%)\end{array}$ & $\begin{array}{c}6 \\
(100 \%)\end{array}$ & $\begin{array}{c}2 \\
(100 \%)\end{array}$ & $\begin{array}{c}25 \\
(100 \%)\end{array}$ \\
\hline
\end{tabular}

Source: Authors

The study reveals that only 1 dry bulk owner and 1 chemical tanker owner use ship management services and 3 general cargo owners have a past experience of outside management. However, the other companies stated that they did not take ship services before and now do not have the willingness to take services of third party ship management companies in the future.

The Turkish ship owners are not much more favorably inclined to using third-party ship management for their vessels. The results of the interviews revealed that the Turkish ship owners have skepticism and hesitancy. They believe that ship management companies cannot give cost effective and high quality services. The owners also argue that the control of the ships must be in their hands. Even the ship owners having the ship management services do not give the commercial management of the ship to ship managers' control.

\subsubsection{Proportion of Third-Party Managed Fleet in Relation to Total Owned}

With regard to the proportion of third-party managed fleet to total owned fleet, Table 9 shows that $80 \%$ of the ship owning companies give the full control of their fleet to the management companies. On the other hand only $20 \%$ of the shipowning companies give $25 \%$ of their fleet to the control of management companies. 
Table 9. Proportion of third-party managed fleet in relation to total owned

\begin{tabular}{|l|c|}
\hline Proportion of third-party managed to total owned fleet & Total \\
\hline $25 \%$ & $1(20 \%)$ \\
\hline $25 \%-49 \%$ & - \\
\hline $50 \%-99 \%$ & - \\
\hline $100 \%$ & $4(80 \%)$ \\
\hline & $5(100 \%)$ \\
\hline
\end{tabular}

Source: Authors

\subsection{Use of Ship Management by the Number of Owned ships}

In this part of the study the aim is to examine whether there seem to be any associations between the different sizes of fleet and the employment of third party ship management company.

Table 10. Use of ship management by number of owned ships

\begin{tabular}{|c|c|c|c|c|c|c|c|}
\hline \multirow{2}{*}{$\begin{array}{l}\text { Use of ship } \\
\text { management }\end{array}$} & \multicolumn{6}{|c|}{ Number of owned ships } & \multirow[t]{2}{*}{ Total } \\
\hline & $1-5$ & $6-9$ & $10-15$ & $16-20$ & $21-30$ & $31-60$ & \\
\hline Yes & $\begin{array}{c}1 \\
(6 \%) \\
\end{array}$ & & & $\begin{array}{c}1 \\
(50 \%)\end{array}$ & & & $\begin{array}{c}2 \\
(8 \%)\end{array}$ \\
\hline $\begin{array}{l}\text { Yes but not } \\
\text { now }\end{array}$ & $\begin{array}{c}3 \\
(19 \%)\end{array}$ & & & & & & $\begin{array}{c}3 \\
(12 \%) \\
\end{array}$ \\
\hline No & $\begin{array}{c}12 \\
(75 \%)\end{array}$ & $\begin{array}{c}3 \\
(100 \%)\end{array}$ & $\begin{array}{c}1 \\
(100 \%)\end{array}$ & $\begin{array}{c}1 \\
(50 \%)\end{array}$ & $\begin{array}{c}2 \\
(100 \%)\end{array}$ & $\begin{array}{c}1 \\
(100 \%)\end{array}$ & $\begin{array}{c}20 \\
(80 \%)\end{array}$ \\
\hline $\begin{array}{l}\text { No but thinking } \\
\text { about it }\end{array}$ & - & - & - & - & - & - & - \\
\hline Total & $\begin{array}{c}16 \\
(100 \%)\end{array}$ & $\begin{array}{c}3 \\
(100 \%)\end{array}$ & $\begin{array}{c}1 \\
(100 \%)\end{array}$ & $\begin{array}{c}2 \\
(100 \%)\end{array}$ & $\begin{array}{c}2 \\
(100 \%)\end{array}$ & $\begin{array}{c}1 \\
(100 \%)\end{array}$ & $\begin{array}{c}25 \\
(100 \%)\end{array}$ \\
\hline
\end{tabular}

Source: Authors

Table 10 indicates that only ship owners having the fleet of 15 and 16-20 categories had relations with ship management companies. The 1-5 category shows that $6 \%$ of the owners use ship management currently and $19 \%$ of owners used in the past management services. When analyzing 16-20 category, the owner has a fleet of 18 ships which consists of 14 tankers and 4 bulk carriers. Since owner is specialized in tankers, the management of 4 dry bulkers has been given to a ship management company. Therefore, the 
bulk carriers can be categorized in 1-5 category. The examination indicates that higher proportion of ship owning firms using professional ship management in 1-5 ships category. So there is an association between different sizes of fleet and the employment of third party ship management companies. In our sample, the ship owning companies which have employed management companies have no management organizations and/or management experiences. Since they are at the beginning of ship management, they start with small fleet and they require the assistance of ship management companies

\subsubsection{Use of Ship Management by the Age of Company}

In this section, it is explored if there is any relationship between the age of the company, the year when it was established, and the frequency of its use of third party ship management companies.

Table 11.Use of ship management by date of company’s formation

\begin{tabular}{|l|l|l|l|l|l|l|l|l|}
\hline \multirow{2}{*}{$\begin{array}{l}\text { Use of ship } \\
\text { management }\end{array}$} & \multicolumn{7}{|c|}{ Date of company's formation } & \\
\cline { 2 - 10 } & $<1950$ & $\begin{array}{c}1951- \\
1960\end{array}$ & $\begin{array}{c}1961- \\
1970\end{array}$ & $\begin{array}{c}1971- \\
1980\end{array}$ & $\begin{array}{c}1981- \\
1990\end{array}$ & $\begin{array}{c}1991- \\
2000\end{array}$ & $\begin{array}{c}2001- \\
2010\end{array}$ & Total \\
\hline Yes & - & - & - & - & - & $1(12 \%)$ & $1(10 \%)$ & $\mathbf{2 ~ ( 8 \% )}$ \\
\hline $\begin{array}{l}\text { Yes but not } \\
\text { now }\end{array}$ & - & - & - & - & - & - & $3(30 \%)$ & $\mathbf{3 ( 1 2 \% )}$ \\
\hline No & - & - & - & $\begin{array}{l}6 \\
(100 \%)\end{array}$ & $\begin{array}{l}1 \\
(100 \%)\end{array}$ & $7(88 \%)$ & $6(60 \%)$ & $\mathbf{2 0}(\mathbf{8 0} \%)$ \\
\hline $\begin{array}{l}\text { No but } \\
\text { thinking about } \\
\text { it }\end{array}$ & - & - & - & - & - & - & - & - \\
\hline Total & - & - & - & $\begin{array}{l}6 \\
(100 \%)\end{array}$ & $1(100 \%)$ & $\begin{array}{l}8 \\
(100 \%)\end{array}$ & $10(100 \%)$ & $\begin{array}{c}\mathbf{2 5} \\
(\mathbf{1 0 0} \%)\end{array}$ \\
\hline
\end{tabular}

Source: Authors

In table 11, we observe that indeed a significant proportion of newly established companies, that is, with less than 10 years in existence, take on third party ship managements. The companies established between 1971 and 1990 did not employ ship managers. When we analyze the owners who have taken on the ship management services, we see that they are newly established unexperienced companies. Another important thing about these companies is that 3 of these owners are involved in holding companies while other 2 are family-owned companies. 


\subsubsection{Reasons for not Using Ship Management}

The reasons of not using third party ship management services by the ship owners are given in Table 12 . The study revealed that the availability of in-house expertise of the ship owning companies was repeated by $100 \%$ of the owners. The lack of confidence in ship management with $75 \%$ took the second place. The desire for control of the ship with $65 \%$ took the third place. Keeping contact with the market took tird place with the rate of $45 \%$. These four reasons are the main points for not taking on ship management services. Although cost minimization by management companies is an important argument, one ship owner argues that costs can be better controlled and minimized if the repairs are done by the company himself rather than by ship managers.

Table 12.Reasons for not Using Ship Management

\begin{tabular}{|l|c|}
\hline Reasons for not using ship management & Total \\
\hline Desire for control & $13(65 \%)$ \\
\hline Lack of confidence in ship management & $15(75 \%)$ \\
\hline Keep contact with market & $9(45 \%)$ \\
\hline Available in-house expertise & $20(100 \%)$ \\
\hline High total costs of ship management company & $2(10 \%)$ \\
\hline Low services quality of ship management company & $2(10 \%)$ \\
\hline
\end{tabular}

Source: Authors

\subsubsection{Types of Management for Firms that use Ship Management}

In connection with the services ship owners tend to be provided with, Table 13 shows that the majority of the firms assign the technical and the crewing management of their vessels to independent managers with the rate of $100 \%$ and $80 \%$ respectively. These two main services are followed by the provisions, operations, and bunkering services with a rate of $60 \%$ each. 
Table 13. Types of Management for Firms that use Ship Management

\begin{tabular}{|l|c|}
\hline Types of management & Total \\
\hline Crewing & $4(80 \%)$ \\
\hline Technical management & $5(100 \%)$ \\
\hline Insurance & - \\
\hline Freight management & - \\
\hline Accounting & - \\
\hline Chartering & $2(40 \%)$ \\
\hline Sale and purchase & - \\
\hline Provisions & $3(60 \%)$ \\
\hline Bunkering & $3(60 \%)$ \\
\hline Operations & $3(60 \%)$ \\
\hline
\end{tabular}

Source: Authors

Employment of outside managers for chartering of the vessels is indeed quite limited and restricted to only $40 \%$ of the total sample. The owners want to keep chartering in their control since it is directly related to the income of the vessels.

\subsubsection{Reasons for Turning to Ship Management}

From the information in Table 14, it becomes clear that the majority of the total sample, $100 \%$, initially turn to outside managers for their expertise. The second most frequently chosen reason for using ship management appears to be not having an in house ship management organization or having an organization but not having enough qualified employees. Third reason is declared as satisfying the ISM requirements by management company and the least frequently expressed reason is cost minimization.

Table 14. Reasons for Turning to Ship Management

\begin{tabular}{|l|c|}
\hline Reasons for turning to ship management & Total \\
\hline Economic pressures/Cost minimization & $2(40 \%)$ \\
\hline Expertise & $5(100 \%)$ \\
\hline ISM requirements & $3(60 \%)$ \\
\hline Not having a ship management organization & $4(80 \%)$ \\
\hline
\end{tabular}

Source: Authors 
In Turkey, some small shipowners with 1 or 2 coaster size vessels sometimes approach the other ship owners or management companies or sometimes even to shipbrokers to charter their vessels since they do not have market potential or in efficiency in foreign language. In this case, shipowners take the responsibility of technical and personnel management and give commercial management to the others.

Another reason for taking management services from other companies is to obtain financial support from the management companies to run the ship. Owners are also taking on management services to have their ship insured with P\&I Club or having insured the ships from highest class insurance companies.

Still another point for using ship management companies is to get the technical know-how from the managers. Some newly established ship owning companies are also taking third party ship management services while they acquire a new ships on credit. Because the creditors want to work with a professional ship management company since the vessels belong to the creditors until the payments of credit. Shipyards are also a good market for the ship management companies during the economical crises. The unsold vessels are given to the management of third party ship management companies.

\section{CONCLUSIONS}

The study revealed that all participating ship owners are familiar with the concept of professional ship management and what that involves. This has made it easy for the authors to conduct this study and to get the perceptions of Turkish shipowners. The first main conclusion reached is that big portion of Turkish shipowners joining the study, $80 \%$ of the sample in the study, do not have the willingness of giving their vessels to the management of third party ship management companies. Although a small portion of the owners take on the management services, they do not frequently assign full management to third parties. Ship owners who declared the use of ship management affirmed that they tend to give out more frequently the crewing and the technical management of their vessels and less frequently the commercial management. This is because of the fact 
that Turkish shipowners traditionally operate their vessels themselves and they prefer to have complete control over them. In fact, Turkish ship owners do not trust in the third party ship management companies. They believe that third party ship management companies cannot give cost effective and high quality services. Even the owners using the third party management companies prefer to keep complete control over the management companies. In other words, Turkish ship owners seem to be skeptical and hesitant in this particular matter.

The study revealed that four types of management organizations exist in Turkey. Vessels are operated by ship owning, owner-managing, manager owning or third party ship management companies. Majority of the companies are ship owning companies, the number of manager owning or third party ship management companies are very limited due to the organizational culture of Turkish shipowrners and their attitudes towards ship management companies. Besides these companies, Turkish owners which operate their vessels under foreign flags establish a ship management company and operate their vessels through this company. So it is a purpose-built fifth type ship management company.

The third party ship management services are mainly taken by dry bulk and tanker owners in Turkey. Especially chemical tanker owners are the major clients of these companies. The reason behind is that chemical tanker market is an emerging and profitable market and due to this reason many investors have invested in this sector without having managerial experience. Therefore, a demand occurred for the highly sophisticated services of the third party ship management companies. Another source of clients is the shipyards which could not deliver the newly built vessels to the owners due to the cancelling of the ship building contract as a result of economical crises.

Although majority of the owners which prefer to use third party managers' services give the control of all fleet to the management company, one owner prefers to give only $25 \%$ of his fleet. The owners who give full fleet to the management companies either do not have managerial experience or an organization to operate their ships. The other aims of the company are to get experience and know-how from the ship management company. 
The study indicates that higher proportion of ship owning firms use professional ship management in 1-5 ships category. So there is an association between different sizes of fleet and the employment of third party ship management companies. The ship owning companies with small fleet require the assistance of ship management companies.

As for the effect of the ship owning company's age on the employment of third party ship management, the results of our study indicates that the ship owning companies which were established in last 10 years are far more likely to turn to third party ship management than any others. Since they are new companies, they have no experience or have no management organizations.

For those shipowners who have never hired outside managers, owners' in-house expertise, a potential lack of confidence in thirdparty ship management itself, their desire to keep overall control over their assets, contact with the relevant markets, high total costs of ship management and low services quality of ship management companies are the most significant reasons for their reluctance to employ third party ship management companies.

Considerable attention was also given to the reasons that make ship owners turn to third-party management. For those owners, expertise of the management company, the ability to relieve the owners from economic pressures, complying with the ISM requirements of the ships and providing ship management organization for the owners were especially stressed as the main reasons for turning to outside managers.

The ships are operated in a competitive market under enhanced legislations which come from international conventions, flag state laws, port state laws and classification societies 'rules. Besides there are economical crises that shipowners cannot control. To deal with all these circumstances, shipowners are required to have enough knowledge and experience. Not all shipping companies can cope with all to survive in the market. Therefore, an outside support, a third party ship management company, may bring solutions to the needs of the owners. This study shows the Turkish ship owners' perception of third party ship management companies. The results of the study may help the companies which want to enter in to the Turkish shipping 
market as a third party ship management company. In the study only $64 \%$ of the total population was reached and these companies are mainly the big shipping companies.

\section{REFERENCES}

BIMCO. (2011) What is Third Party Ship Management, https://www.bimco.org/en/Corporate/Education/Seascapes/Questions_ of_shipping/What_is_3rd_party_ship_management.aspx , 16.05.2010.

CHIN, C. N. (2008) Labour Flexibilization at Sea "Mini United Nations"' Crew On Cruise Ships, International Feminist Journal of Politics, Vol.10, No.1, pp. 1-18.

CELIK, M. (2009) Establishing an Integrated Process Management System (IPMS) in Ship Management Companies, Expert Systems with Applications, Vol.36, pp. 8152-8171.

DOWNARD, J.M. (1996) Managing Ships, Fairplay Publications Ltd., 4th ed. England.

GILBERT, H. (1993) International Ship Management: The Right Product at the Price, Lloyd's of London, London.

INTERMANAGER. (2011) About Intermanager, http://www.intermanager.org/, 01.07.201.

KOUFOPOULOS, D. N., LAGOUDIS, I. N., THEOTOKAS, I. N., SYRIOPOULOS,T. C. (2010) Corporate Governance and Board Practices By Greek Shipping Management Companies, Corporate Governance, Vol.10, No.3, pp. 261-278.

KLIKAUER, T, MORRIS, R. (2003) Human Resources in the German Maritime Industries: 'Back-Sourcing' and Ship Management, The International Journal of Human Resource Management, 14664399, Vol. 14, No.4, pp. $544-558$.

MITROUSSI, K. (2003) Third Party Ship Management: The Case of Separation of Ownership and Management in the Shipping Context, Maritime Policy and Management, Vol.30, No.1, pp.77-90. 
MITROUSSI, K. (2004a), The Ship Owners' Stance on Third Party Ship Management: An Empirical Study “, Maritime Policy \& Management, Vol.31, No.1, pp. 31-45.

MITROUSSI, K. (2004b), “The Role of Organizational Characteristics of Ship Owning Firms In The Use Of Third Party Ship Management”, Marine Policy, Vol.28, No.4, pp. 325-333, July 2004.

PANAYIDES, P.M. and GRAY, R. (1997) Marketing the Professional Ship Management Service, Maritime Policy \& Management, 14645254, Vol.24, No.3, pp. $233-244$

PANAYIDES, P.M. and GRAY, R. (1999) An Empirical Assessment of Relational Competitive Advantage in Professional Ship Management, Maritime Policy \& Management, 1464-5254, Vol.26, No. 2, pp. $111-125$.

PANAYIDES, P.M. (2001) Professional Ship Management, Marketing and Strategy (Plymouth Studies in Contemporary Shipping and Logistics), Ashgate Publishing.

PANAYIDES, P.M., CULLINANE Kevin P. B. (2002) The Vertical Disintegration of Ship Management: Choice Criteria For Third Party Selection And Evaluation, Maritime Policy \& Management, , Vol. 29, No.1, pp. $45-64$.

PANAYIDES, P.M. (2003) Competitive Strategies and Organizational Performance In Ship Management, Maritime Policy \& Management, 464-5254, Vol.30, No.2, pp. 123-140

RAGHURAM, G., ASOPA V.N., BHATNAGAR, D., DIXIT, M.R., RAMANI, K.V., RAO, V.V., SINHA. S. (1998) Ship Management, Cases and Concepts, First Edition, Macmillan India Limited.

SHIPMAN 2009. (2009)

https://www.bimco.org/ /media/Documents/Document_Samples/Sund ry_Other_Forms/Sample_Copy_SHIPMAN2009v2.ashx, 25.06.2010 
SHIPMAN 98. (1998)

https://www.bimco.org/ /media/Documents/Document_Samples/Sund ry_Other_Forms/Sample_Copy_SHIPMAN_98.ashx, 25.06.2010

SLETMO, G.K. (1986) The Transformation of Shipping and the Role of Ship Management. In: Heaver Trevor D, editor, Research for Tomorrow's Transport Requirements, Vancouver: Centre for Transportation Studies, University of British Columbia, World Conference on Transport Research, Vol. 1, pp. 734-46.

SLETMO, G. K. (1989) Shipping's Fourth Wave: Ship Management and Vernon's Trade Cycles, Maritime Policy \& Management: 14645254, Vol.16, No.4, pp. 293 - 303.

TALLACK, R. L. (2000) Commercial Management for Shipmasters, A practical Guide, The Nautical Institute.

UNCTAD (2010) Review of Maritime Transport.

WILLINGALE, M., FAVRE, D., FRITZNER, O, GILBERT, H., LANG, D., LAWFORD, H.M. P., RODGER, D. (1998) Ship Management, 3rd. Edition, LLP Hong Kong, Lloyd's of London Press, London. 